\title{
LIABILITY OF VEHICLE OPERATORS FOR BUILDING DEFECTS - POSSIBILITIES BASED ON DOCTRINAL AND COMPARATIVE EXPLICATION
}

\author{
Norbert Adamov \\ Comenius University in Bratislava, Faculty of Law
}

\begin{abstract}
By operation of means of transport some damage may not appear suddenly but after long repeated influence. In such cases application of causality test 'conditio sine qua non' leads to the result that if it is not possible to determine some liable persons unambiguously, damages bears the damaged person. Such a conclusion is not in accordance with the conception of the heightened level of legal protection of damaged persons in cases of strict liability, which is also liability for damages caused by operation of means of transport. The solution may lies in the application of alternative causality tests.
\end{abstract}

Key words: solidarity, liability, means of transport, damage, wall cracks

\section{INTRODUCTION}

One of the externalities joined with operation of means of transport are also static faults of buildings standing near of roads. These faults are caused by dynamic factors that act adversely on the building in two ways: On one hand, passing through the subsoil to the base of the building, and hence through the supporting structure upward. These shocks cause small cracks in different parts of buildings, especially around doors or windows. On the other hand, dynamic shocks may, however, also cause an excessive consolidation of base soils and unequal (differential) settlement may cause significant problems for buildings. ${ }^{1}$

It is obvious that property of owners of these objects is harming and it has at least an aesthetic impact. However, it cannot be excluded that occurrence of such failures can substantially affect the habitableness of concerned buildings. Last but not least, such externalities have also a considerable impact on the price of real estates in the case of selling.

In one corner, the externalities in the vicinity of roads have theirs origin in the economic development, which brings out expansion of freight transport. In other corner, political decisions have also a great impact. ${ }^{2}$ For instance, changes in road infrastructure charging for vehicles above 3.5 tonnes in the past has led to an enormous increase of traffic on some roads and directly to the increase of negative impacts on the concerned territories. However, these externalities are not only harmful to the property of the concerned entities. In the online discussion forum of the Ministry

1 Anonym: Statické poruchy. 2011 (online) Accesible via: <http://www.statickeposudky.info/poruchy.html>. Access Date: November 16, 2016.

2 The list of delimited sections of roads is stipulated in the executive regulation of the Ministry of transport and construction of the Spovak republic Nr. 475/2013. 
of Transport of the Slovak Republic ${ }^{3}$ one can read contributions which reffer to significant discomfort in housing, which can also be defined as non-property damage consisting in the loss of ,joy of housing".

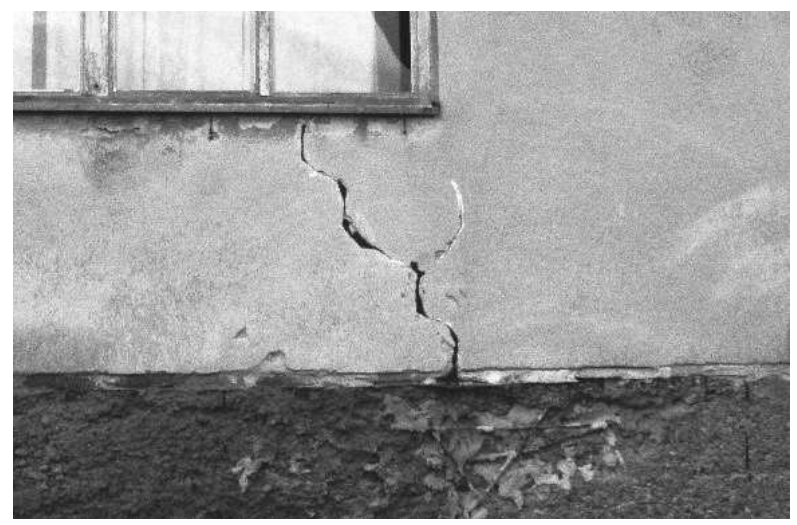

An axample of the building structural defect

\section{SEDES MATERIAE}

The number of heavy goods vehicles is a factor that is directly proportional to the potential to damage the road itself as well as the buildings nearby. It is the right of hauliers to use all roads if there is no traffic constraint. From the point of view of public law it is necessary to distinguish between:

(a) local weight limitation - typical examples are bridges on minor roads and

(b) weight limits applicable throughout the territory of the state.

The operator of an overloaded vehicle can be penalized under administrative law. The interest to prevent increasing of the road body destruction is thus somewhat reached, even though roads are also pretty weighted down by heavy goods vehicles however weight has not exceeded the specified limit. But as far as the private property interests of real estate owners are concerned, in cases of static failure caused by transit of heavy (or overloaded) heavy goods vehicles to hold somebody to account seems complicated.

The court practice ${ }^{4}$ has found that damages caused by transit of heavy goods vehicles is not damage caused by operation of the means of transport but must be considered as damage caused by a particularly dangerous operation ( $\$ 432$ of the Civil Code). These decisions in question solved liability for damages caused by transit of lorries and other heavy machines involved in construction activities. The conclusion that such damages should be accounted as damages caused by particularly hazardous operation could be reasonable only if the area where damages occurred could be regarded as part of the building site, because movement of means of transport in the frame of construction site is not considered for operation of means of transport within the meaning of $\$ 427$ Civil Code,

3 See <http://www.telecom.gov.sk/index/index.php?ids=36291\&prm1=101\&prm4 Access Date: December 12, 2016

4 See decisions of the Czech Supreme Court 25 Cdo 972/2000 and 25 Cdo 972/2000 which states that as far as an haus near of a road is concerned as particular dangerous operation should be considered also periodic and repeted passing of heavy building machines which cause excessive loading of this road, which is not appropriate from the structural poin of wiev. 
according to the decision $\mathrm{R} 3 / 1984$. But such a conclusion is not verisimilar because the decisions of the Supreme Court of Czech Republic 25 Cdo 972/2000 alike 25 Cdo 972/2000 expresses that the passage of the machinery has caused an ,excessive burden on the road.

An explanation of why (in the above-mentioned judgments) the court considered the damage was caused by particularly dangerous operation, it must be sought that in the traditional view of causality, in the sense of the 'conditio sine qua non' test, a damage caused by some means of transport should be the result of its one-off and immediate harmful impact. As in the cases in question, there was repeated detrimental effect of a large number of vehicles which were operated by one operator (a building company), the court concluded that this operator is the operator of the particularly dangerous operation. Of course, such a verdict is possible in this case, but it is questionable, whether it is also the best systemic solution.

If we were to look through the prism of „increased danger“ as the reason for which the legislator defined the cases of strict liability for damages associated with objective liability, then it would be necessary to consider whether particularly dangerous operation is such a specific type of risk that under certain circumstances some operation of means of transport is considered to be a particularly dangerous operation.

If we look at the case in question through the prism of the liable person, then we could draw a conclusion that if the damage is caused by repeatedly damaging effects of one means of transport it should be subsumed under liability of the operator of this means of transport. But in the case that damage is caused by many vehicles and these are operated by one operator, such a damage should be subsumed under liability of operator of particularly dangerous operation.

If we look through the prism of the technical device that caused the damage, then it would be possible to assume that the succesive and cumulative harmful effect of individual technical system (trucks for instance) gives rise to liability for the damage only if:

(a) these technical devices are operated by one operator

(b) and since the individual partial harmful effects can not be considered as causality of the 'conditio sine qua non' type and another causality is not considered by the court to be relevant and therefore it is necessary to look at the harmful action as a whole, which is apparently possible only in the event that the damage caused will be considered as damage caused by particularly dangerous operation.

Paradoxically, if the court accepts that the damage (caused by particularly dangerous operation) can be considered as a whole, it is unclear why the same damage can not be considered as the damage caused by the cumulative detrimental effect of means of transport (operated by one operator). I take the view that, where special liability (liability without fault) for damages caused by operation of means of transport has been established, damages caused by means of transport should be deducted exclusively from that title.

Conversely, liability for damages caused by particularly hazardous operation must be carried out in cases which are not specifically regulated in the Civil Code. However, if the person causing some damage by particularly dangerous operation 'is liable as an operator of a means of transport' (as it is written in the $\$ 432$ of the Civil Code), it is not meaningful to refer to $\$ 432$ of the Civil Code if a damage was caused by such technical devices which should be regarded as a means of transport in the civil law sense. Replacing liability of operator of means of transport with liability of operator of particularly hazardous operation could have some rationality only if such liability was different (even more stringent, for instance). 


\section{DOCTRINAL VIEW ON ARISING OF LIABILITY}

In order to establish civil liability, it is firstly necessary to conclude whether there is any damage caused by the traffic load (due to noise, dust or vibration). As mentioned above, as far as the consequences of building structural defects are concerned, the existence of damages is apparent. If damage arises, it is necessary to determine what caused this damage.

According to $₫ 427$ of the Civil Code, the operator is liable for the damage caused by the special nature of the operation. The collocation "circumstances, which have their origin in operation", is used in the following $\$ 428$ of the Civil Code - there are specified circumstances under which the operator may be released from non-faulty liability, as well as the circumstances which cause that liberation is excluded. For the assessment of liability of an operator of means of transport, the $\$ 428$ $\mathrm{CC}$ is therefore as substantial as the $\$ 427 \mathrm{CC}$.

The formulation that operators are liable for damages caused by the particular nature of the operation can be interpreted in such a way that the damage can not be inflicted by the nature of the particular operation directly but there must be some circumstance that is a necessary intermediate between the occurrence of the damage and the phenomenon resulting from the nature of the operation. Thus, only a specific circumstance may be the cause of a particular damage, This circumstance is specific and directly related to:

(a) physical phenomena accompanying operation of means of transport; or

(b) control of means of transport by persons or by automatic systems; or

(c) other service staff activities related to transport services.

In cases of building structural defects caused by heavy goods vehicles

(a) the phenomenon resulting from the particular nature of the operation may be considered to be the high mass and the wheel circumvolution and

(b) the circumstance that inflicts a static disorder should be considered to be vibrations induced in the subsoil, what possibly cause changes in the subsoil as a result of the repetitive vibration impact.

Eliáš interprets the special nature of traffic as an operational and technical characteristic that distinguishes the operation of means of transport from other operations. A circumstance originating in the nature of the operation is, as such, to be interpreted as not capable of originating in any mode of operation but in its particular nature, i.e. in the operational or technical condition of means of transport (or equipment) which is not normal (see the decision R 9/72) and it is irrelevant whether the means of transport has undergone technical tests and that it has an official technical worthiness to operate. ${ }^{5}$

If the liability for static disruptions caused by heavy traffic would be assessed according to circumstances that originated in some mode of operation of means of transport, as interpreted by Eliáš, it would not be possible that liability for static disruption caused by transport can arise (unless it is caused by overloaded heavy goods vehicle) because vibrations are an immanent part of its operation. Therefore, if the vehicle is not overloaded, it is not acceptable to claim that vibrations are the result of a defective (abnormal) technical condition of such a means of transport. If the court were to assume that liability for damage caused by operation of means of transport must be linked to an

5 ELIÂŠ, K. et al. Občanský zákoník. Velký akademický komentáŕ - 1. svazek, p. 885. 
„abnormal“ state, in other words, that there must be a failure (whether a technical failure or a failure of the crew or another personnel) the externality without which the operation of a particular means of transport is not conceivable could not be considered harmful. However, such a solution can not be accepted because it would considerably disadvantage the injured person.

Novotná pertracts a similar interpretation, namely that the internal circumstances are mainly various defects and deficiencies of means of transport (deviations from the normal operational technical state) ${ }^{6}$ However, the use of the word 'mainly' in the quoted thesis (unlike Eliášs s formulation) does not exclude arising of liability if, in the given case, there is no technician failure or failure of the operator.

However, it can be considered as 'abnormal' if a heavy goods vehicle is overloaded to the extent that its operation is not allowed on any road. In any case, an administrative penalty in the form of a fine does not restrict to claim civil damages. In the case that police will reveal some overloaded heavy goods vehicle on a given section of road (where static disruption of buildings had occurred), the position of the damaged person would be strengthened. Under the joint responsibility of a number of wrongdoers (i.e. truck operators whose police have detected as overloaded), compensation could be claimed not only by the owners of the damaged buildings but also by the owner of the damaged road, with the fact that structural parameters and limits of the road in question are given and damages caused by overloaded vehicles are commonly known and as results of technical observations (as the notorious fact), must not be proven in civil proceedings. Such a presumption could also be applied in relation to cracked buildings.

However, operators of heavy goods vehicles who did not exceed the permitted weight (or weight was not checked by the police), they may object to contributory negligence of the injured party (the local authority as the highway administrator) in the fact that, knowing the possible harmful consequences, the traffic of heavy goods vehicles have not been excluded by traffic signs. Although it is necessary to take contributory act into account in some specific case, it should be assumed that liability for damages caused by operation of means of transport is also given in cases where:

(a) damages has arisen as a result of an act which is not prohibited by public law; and

(b) is a breach of rules laid down by public law, but in the frame of civil liability the liable person can not invoke the fact that he (or she) has already been fined under administrative responsibility. ${ }^{7}$

If it is clear that some damage has arisen from circumstances which have originated in the operation of a means of transport, it must be assumed that in those cases it is not a case of force majeure and therefore the operator would not be able to shake of liability for this damage. On the practical level, however, there are several problems with liability, as far as cracked walls (due to vibrations caused by heavy freight) are concerned.

First of all, it is a question of how to define a range of liable subjects. While it is obvious that there is a causal link between the heavy goods vehicle operation and harmful vibrations, it is generally not possible to determine that the damage was caused by a particular vehicle, and in spite ofv the fact walls cracked after passing a particular vehicle, it is very difficult to prove that.

6 NOVOTNÁ, M. Zodpovednost za škodu spôsobenú prevádzkou dopravných prostriedkov. In ŠTEVČEK. M., DULAK, A., BAJÁNKOVÁ, J., FEČÍK, M., SEDLAČKO, F., TOMAŠOVIČ, M. et al. Občiansky zákonník I. \$1-450. Komentár, p. 1424.

7 NOVOTNÁ, M. Zodpovednost za škodu spôsobenú prevádzkou dopravných prostriedkov. In ŠTEVČEK. M., DULAK, A., BAJÁNKOVÁ, J., FEČÍK, M., SEDLAČKO, F., TOMAŠOVIČ, M. et ak. Občiansky zákonník I. § 1-450. Komentár, p. 1406. 
Unlike damages to health caused by exhalations produced by means of transport, it is more realistic to identify a possible range of liable subjects in cases of damages caused by vibrations. For example, it is possible to install an automatic device that takes photographs of each passing vehicle, and from these photos it is possible to make a selection of vehicles which have the potential to cause static disruptions of homes built alongside. Based on the registration numbers, it is possible to identify the operators of these means of transport (assuming that after the monitored section there was no change of the operator, for example as a result of the transfer of the ownership right). If new cracks occured during the monitored period, this would be a significant factor for taking liability towards the so-called circle of liable entities.

However, if a particular wall cracked before the monitoring began, then the defendant may object to the absence of a causal link, with the fact that when they were passing through, such damages already existed. However, the damaged subject could argue that specific means of transport were regularly passing through the village in the past, even at the time when the damage began to appear, but this should be supported by some evidence. An operator of a heavy goods vehicle could also argue that damaged buildings were improperly designed, or the actual construction of the damaged object was made in the wrong way and this contributed to the damage. As far as damage to the road body itself is concerned, operators could object that the operator as a person using the vehicle paid road tax, which can be interpreted as a lump sum compensation for increased road wastage.

However, in terms of the basic assumptions for liability for damage caused by operation of means of transport, it is not disputed that vibrations are circumstances which have their origin in the operation of means of transport because:

(a) they arise as a result of the movement of a vehicle on the road, that is to say when moving from point A to point B,

(b) they arise as a result of rotating wheels, the intensity and hence the degree of damage being a matter of great weight, and both of which may be described as such which arise from the particular nature of means of transport and constitute an essential part of its operation.

If another reason for the cracking of walls on houses standing near roads is excluded by expert judgment, the causal link between the event and the harmful consequences is obvious. But the problem may be that this causal link can not normally be considered as immediate.

\section{THE PROBLEM OF THE CAUSALITY}

Since the linearity of causalities must be circumscribed by some normative criteria, for example: by protective purpose of legal standards, by foreseeability of harm and, in particular, by adequacy and immediacy of causes, using of the 'conditio sine qua non' test is generally accepted. ${ }^{8}$ The 'conditio sine qua non' conditionality test is formulated in the PETL (Principles of European Tort Law) in the Article 3: 101 as the act or omission which is the cause of the damage if, in the absence of such proceedings, the damage did not arise.

The Czech Supreme Court in the decision no. 25 Cdo 1946/2000, formulated a broader interpretation, in which the chain of causes are in focus: The relationship of causal link is when the dam-

8 DOLEŽAL, A. - DOLEŽAL, T. Kauzalita v civilnim pravu se zaměřenim na medicinskopravni spory, p. 63. 
age has arisen as a result of the illegal act of the wrongdoer, that is, if his behavior and the harm are in the relationship of the cause and effect, and therefore, if it is proved that if there was no unlawfully act it would not be the damage. If the cause of the damage is different, liability for the damage does not occur; the cause of the damage can only be the circumstance without which the damage would not have arisen. In this case, the cause must not be the only one, but it is sufficient if it is one of the causes that contributes to the adverse consequences for which the compensation is due, and that the cause is substantial.

If there are more causes, they act either concurrently or subsequently, without overlapping over time; in such cases there is a need for a causal connection to make the string of successive causes and consequences related to the cause of the damage so closely connected (the primary cause immediately caused the different cause and this possibly caused the another cause) that from the impact of primary cause may be established a factual link with the occurrence of a detrimental effect.

The temporal aspect is not decisive, and causal link can not be confused with the temporal link, since injury can be the result of a damaging event, even though it did not arise at the time of the event, but later (see the decision published under no. 7 in the Court of judgments and Opinions, 1992). The existence of a causal relationship can not therefore be related only to the cause of the 'closest' consequence... On the other hand, if the other fact goes into action, which has no relation to acts of wrongdoer, a chain of causes does not establish a causal link between the act of the wrongdoer and the damage. The causal link is interrupted even in those cases where the immediate cause of the damage is a fact which is the very consequence for which the wrongdoer is liable for another legal reason.

The use of the 'conditio sine qua non' test is well-founded in cases where the damage was caused by one subject and caused by one cause. It can not be ruled out that circumstances such as speed, extraordinarily high weight or poor road surface have caused intense vibrations and these vibrations caused a building structure defect as a result of passing of one heavy goods vehicle and thus such a damage was caused by one operator of a means of transport.

However, if we assume that the harmful consequence (cracking of the wall for instance) certainly caused just one of several events, but it is not possible to find out which and therefore can not be detected a 'real' wrogdoer, in such cases it is advisable to consider alternative causality (which is manifested either simultaneous or cumulative effect of multiple causes).

Simultaneous causality is detrmined by more independent conditions, each of which is itself capable of bringing harmful result. There may be a situation where in both directions is a number of overloaded trucks that are going to miss each other in front of a building in question. Although the strongest vibrations are caused by vehicles at a point that is most critical for this building, other vehicles moving in the vicinity, though not yet powerful, also produce vibrations that can still increase the vibration effect of vehicles located in the point of the most intense action.

If the so-called strong 'conditio sine qua non' test (that is to say, when the phenomenon of consequence is viewed as only one necessary condition without which the consequence would not occur), it would lead to the conclusion that if at that moment some of the vehicles in operation will be stopped, the consequence would still be the result of the physical action of the others vehicles. Therefore, the action of any of the vehicles located at a significant distance from the building is not a necessary condition for the occurrence of a detrimental effect.

According to the Swiss legal doctrine, in the case of damage caused by any of several potential wrongdoer, no one is liable. The Swiss theorist von Tuhr justifies this approach by the following example: If the room from which a valuable thing was stolen during the day visited three people and 
we do not know who of them is the wrongdoer, on the basis of the joint liability, all three would have to be liable, and such a solution must be refused. ${ }^{9}$

Another solution in the case of simultaneous causality came to court in the American case Corey vs. Havner in $1902 .{ }^{10}$ There were two motorcyclists who were at the same time passing around a horse that had been frightened by strong motorbike sounds, and startled injured the plaintiff. The judge ruled that both defendants in this case bear the same liability because it is not possible to determine what proportion of the harmful outcome each of them has.

Arising of co-liability in cases of simultaneous causality is also admitted by the PETL. In such cases, however, PETL does not accept joint liability, but essentially only several, as it results from the Article 3: 103 (2) as the principle of proportionality: If, in case of multiple victims, it remains uncertain whether a particular victim's damage has been caused by an activity, while it is likely that it did not cause the damage of all victims, the activity is regarded as a cause of the damage suffered by all victims in proportion to the likelihood that it may have caused the damage of a particular victim.

When considering the causality, in cases of 'crackling walls' we should acnowledge the fact, that although one particular passage did not immediately cause a particular crack, it contributes to the stress of the building structure, which in the case of repeated actions may cause later cracking or enlargement of existed cracks. Every passage of a heavy goods vehicle can also cause changes in subsoil and these changes may be continuous. At certain time point, when the critical limit is exceeded, cracks will occure. In this case, however, it is not a chain of causes (as in the 'conditio sine qua non' test), that cause $A$ leads to cause $B$ and this caused cause $C$ which caused the harmful consequence $\mathrm{X}$, but independent causes (single passes) A1, A2, A3 ... cause instability of subsoil (cause B), and this instability leads to static disturbances, which is the detrimental effect $X$.

In cases of cumulative causality (as another type of alternative causality) causality is not present in full force, but only potentially. ${ }^{11}$ Bydlinski and Koziol prefer jointly liability of wrongdoers and argue it is better if in cases of unsafe causality possible wrongders and not harmed persons bear the burden. ${ }^{12}$ In Germany, there is a solidarity of wrongdoers in such cases expressis verbis established in the BGB, $₫ 830$ para. 1, in the Czech New Civil Code this handles $₫ 2915$ para. 1, and in Austria it is resolved by a doctrine accepted by judicial decisions of the courts.

If damage arises as a result of shocks, it can be argued that even if a particular crack was caused by a particular passing of a heavy goods vehicle, tdamages would not arise if the structure in question had not been exposed for a long time to similar shocks. If, therefore, the conduct of other entities created conditions for the occurrence of damage, it is not essential which of passing heavy goods vehicles caused the appearance of the damage immediately.

Another way how to correct the paradoxes that would result from 'conditio sine qua non' in cases of alternative causality is using of the NESS (what is a test of factual causation). According to the NESS theory (Richard Wright is the originator), a specific condition is a cause of a specific consequence only if it was a necessary element in a set of current conditions that were sufficient for the occurrence of such a consequence. The use of this test is appropriate in cases of simultaneous causality (when each of the simultaneously acting causes would in itself cause some consequence)

\footnotetext{
9 VON TUHR, A., cited from DOLEŽAL, A. - DOLEŽAL, T. Kauzalita v civilnim pravu se zaměřenim na medicinskopravni spory, p. 152.

10 Henry A. Corey vs. Lud C. Havener. Same vs. A. L. Adams, 182 Mass. 250, 1902.

11 DOLEŽAL, A. - DOLEŽAL, T. Kauzalita v civilnim pravu se zaměřenim na medicinskopravni spory, p. 152.

12 KOZIOL, H. Basic questions of tort law from a Germanic perspective, p. 144
} 
as well as cumulative causality (when at least one of the causes itself would not cause such a consequence).

As already mentioned above, in the case of cumulative causality, the harmful consequence arises from an action of two or more causes, but one of the causes alone can not cause a detrimental effect. It is not essential whether the cumulation occurs through a sequence of causes (ie, a repetitive detrimental effect) or by multiple causes at the same time. A case of cumulative causality will occur not only when two heavy goods vehicles are passing each other near of a threatened building, and this is the reason that vibrations are so intense that walls cracks, but also in the case of a sequence of individual passes that are destructive towards subsoil.

Within the framework of cumulative causality, it is possible to work with a model situation that a harmful consequence would not occur if the physical action was not repeated and at a certain intensity. Although in most cases the passage of a particular heavy goods vehicle does not directly cause a particular crack, such a through passage of a particular vehicle would not cause this damage unless the subsoil has been disturbed by a serie of previous transits. Similarly, cracks would not be increased if there were no subsequent shocks caused by through passages of next heavy goods vehicles after the crack appeared. From this point of view, not only the passage of a vehicle, due to which a particular wall cracked but all previous transits created conditions for the apparent and consecutively increased damage. Therefore all previous transits can be considered as the necessary element in the set of current conditions.

Similarly, it is possible to point to the case which state Hart and Honore: Subjects A and B assembled garbage for a while at the wall belonging to the neighbor $\mathrm{C}$. On one day, this weight caused a destruction of this wall. Thus, in cases of cumulative causality, each of this events can be considered as NESS and should therefore be regarded as a cause, even if such a cause has a minimal effect on the occurrence of the detrimental effect. A possible limitation of liability in such a case is not a matter of factual causality, but the matter of a policy-normative decision. ${ }^{13}$

A different view how to deal with cumulative causality in cases of static disturbances (caused by vibrations and shocks due to the passage of heavy goods vehicles), provides von Kries's theory of adequate cause. According to this theory for an adequate cause can be marked just such a condition that significantly affects the existence of a consequence or significantly increases the likelihood of its occurrence. In the light of this doctrine, the mere passing of a heavy goods vehicle throgh towns or villages that does not immediately cause the occurrence of some crack can not be described as an action which significantly affects the occurrence of a consequence, because a harmful consequence arised after several hundreds or thousands of through passage of heavy goods vehicles. According to von Kries, an adequate condition does not have to be one cause, but there can be more causes. For instance, such causes may be specific attributes of the subsoil as well as attributes of buildings that were not designed to withstand without failure certain stress of construction.

An objective criterion for determining an adequate cause is, according to von Kries, the distinction whether other fact ordinarily cause such a consequence (thus, there is an objective generalization possible), or the same fact causes a similar result only rarely, for example by chance. ${ }^{14}$ If cracks occurred on many objects standing along the entire stage and a similar situation exists also in other towns or villages, then it is possible to incline towards the statement that the transit of heavy goods

13 DOLEŽAL, A. - DOLEŽAL, T. Kauzalita v civilnim pravu se zaměřenim na medicinskopravni spory, p. 128.

14 VON KRIES, J. A. Über den Begriff der objectiven Möglichkeit und einige Anwendugen desselben. VjSchr. f. wissenschaftl. Philosophie 1888, p. 200. Quoted according to DOLEŽAL, A. - DOLEŽAL, T. Kauzalita v civilnim pravu se zaměřenim na medicinskopravni spory, p. 88. 
vehicles, linked-up to other factors (the construction and technical dimensions of the road, state of the subsoil, static dimensiones of objects in question) tend to cause such damages. However, if it is only an objectively increased likelihood of a harmful consequence, (according to von Kries) this can not be considered an adequate cause of harmful consequence. ${ }^{15}$

Hart and Honore lean to similar solution in their example of cumulative causality: Each of the wrongdoers gave a small dose of poison to the injured person. This dose on its own, can not have a significant effect after a drink, but a certain multiple of such a small dose may cause death. In this case a separate procedure each of wrongdoers does not increase the risk of death, because it can not be presumed that other individuals would have given additional doses of poison to the beverage in question independently of each other. ${ }^{16}$ It may be argued that the application of this method of thinking in the 'cracked walls' case is not entirely adequate, since in the case in question it is liability for the culpable behavior and the assumption of liability being based on the knowledge that there is a possibility of a harmful consequence. In the case of transit of heavy godds vehicles through towns and villages the cumulative causality can not be eliminated by the fact that the operator is not aware that his (her) means of transport is only one of many that produce externalities. In addition, in the case of strict liability, the assessment of such a knowledge is irrelevant.

Legal systems apply an 'all or nothing' rule that leads to two results - either the damaged subject is able to prove the existence of a causal nexus and will receive full compensation or does not prove that existence and will get nothing. However, the application of this rule appears to be problematic in legal disputes where the causal relationship is more or less likely. ${ }^{17}$

As far as determination of causal nexus is concerned, different rules are laid down in this respect in different countries. In the Slovak or Czech Republic, the causal link should be demonstrated with certainty. Here, I can point out the decisions R 21/1992 and 25 Cdo 168/2003, where the Supreme Court of the Czech Republic stated that: The causal link between the culpable wrongful act of the defendant and the damage to health must be safely proved; the probability is not enough. ",

On the other hand, however, there are also decisions that allow the determination of causality based on probability. For example, the decision of the Czech Supreme Court 25 Cdo 1628/2013 states that: ... the experts quoted the probability of $70 \%$ to $80 \%$ are sufficient to conclude about the causal link between wrongful proceedings of the defendant and the death of the injured person.

The causal relationship between static disturbances and the operation of a particular heavy good vehicle can therefore be analyzed through the prism of hypothetical causality. Two approaches are possible here:

(a) If the cause A immediately caused the damage, then following causes (causes B, C, D...) are irrelevant to the emergence of liability, in spite of this that if there was no cause A and the damage would cause any of the following causes. ${ }^{18}$

(b) On the other hand, in the PETL Article 3: 104 (3) states that: If the first activity has caused continuing damage and the subsequent activity later on also would have caused it, both activities are regarded as a cause of that continuing damage from that time on.

15 For example, if someone is forced to spend a night in an other city because of an accident on the railway line and he (or she) get infected with an infectious disease. See: HART, H. L. A. - HONORE, T. Causation in the law, p. 486. Quoted according to DOLEŽAL, A. - DOLEŽAL, T. Kauzalita v civilním právu se zaměřením na medícinskoprávní spory, p. 88.

16 HART, H. L. A. - HONORE, T. Causation in the law, p. 492. Quoted according to DOLEŽAL, A. DOLEŽAL, T. Kauzalita $\mathrm{v}$ civilním právu se zaměřením na medicínskoprávní spory, p. 88 .

17 DOLEŽAL, A. - DOLEŽAL, T. Kauzalita v civilnim pravu se zaměřenim na medicinskopravni spory, p. 181

18 DOLEŽAL, A. - DOLEŽAL, T. Kauzalita v civilnim pravu se zaměřenim na medicinskopravni spory, p. 146. 


\section{CONCLUSION}

It is clear based on the examples provided above that damages resulting from repeated transit of heavy goods vehicles are real and are caused by the specific nature of the operation of the means of transport. The problem is, how to determine the causal nexus. There are several possible approaches that can lead to different outcomes. But it is essential that 'conditio sine qua non' is not the only causality test that can be used in such cases.

If some damage caused by the operation of a means of transport is linked to the operator's strict liability, and such a damage can not be caused solely by one wrongdoer, it is not in accordance with the principles of justice that burden of damage lies with the injured person only, because the damage results from a cumulative action. In these cases, a solution is offered in one of the alternative causality tests. If the use of alternative causality should be rejected on the grounds that such a way of determining causality has no tradition in Slovak or. Czech (or previous Czechoslovak) law, it would be contrary to the fact that the reason why the lawgiver established strict liability of operators of means of transport is that damaged person should get a compensation easily and faster.

One of the tools which provides high level of protection of damaged persons is also the solidarity of wrongdoers. In the case that the defendant operators lose his dispute, it is up to them to identify the other jointly liable operators and apply regress to them. Taking joint liability for heavy goods vehicle operators can appear very strict, as it is unrealistic to identify all the co-liable entities, but in such cases, the owners of homes or road owners are also very vulnerable.

Obviously, strict liability, in conjunction with joint liability and alternative causality, leads to the conclusion that it is possible to lay claim towards any of the subjects who have cumulatively contributed to the damage. If such a conclusion were considered to be absurd, as it could be hundreds, or perhaps thousands of the joint liable operators of heavy goods vehicles in one case, then it would be advisable to resolve this paradox in the frame of preparation of the new Slovak Civil Code.

\section{Bibliography:}

Anonym. Statické poruchy. 2011 (online) Accesible via: <http://www.statickeposudky.info/poruchy.html>.

DOLEŽAL, A. - DOLEŽAL, T. Kauzalita v civilnim pravu se zaměřenim na medicinskoprávni spory. Praha : Ustav statu a prava AV ČR 2016. 261 p. ISBN 978-80-87439-27-2.

ELIÁŠ, K. et al. Občanský zákoník. Velký akademický komentář - 1. svazek. Praha : Linde, 2008. 1391 p. ISBN $978-$ 80-7201-687-7.

HART, H. L. A. - HONORE, T. Causation in the law. $2^{\text {nd }}$ ed. New York : Oxford University Press, 1985. 516 p. ISBN $01-$ 982-5474-1.

MOORE, M. S. Causation and responsibility: an essay in law, morals, and metaphysics. New York : Oxford University Press, 2009. ISBN 01-992-5686-1.

LUBY, Š. Prevencia a zodpovednost’ v občianskom práve. Bratislava : SAV 1958.

ŠTEVČEK, M., DULAK, A., BAJÁNKOVÁ, J., FEČÍK, M., SEDLAČKO, F., TOMAŠOVIČ, M. et al. Občiansky zákonník I. \$ 1-450. Komentár. Praha : C. H. Beck, 2015. 1616 p. ISBN 978-80-7400-597-8.

WRIGHT, R. W. Causation in Tort Law. California Law Review. 1985, Vol. 73, p. 1735-1828. Also accesible via: $<$ http://scholarship.law.berkeley.edu/cgi/viewcontent.cgi? article=2030 \& context=californialawreview $>$.

WEINBERGER, O. Norma a instituce. Úvod do teorie práva. Brno : Masarykova univerzita, 1995. ISBN 80-2101123-8. 
KOZIOL, H. Basic Questions of Tort Law from a Germanic Perspective. Wien : Jan Sramek Verlag, 2012. ISBN 978 3-902638-85-4. Also accesible via: <http://www.jan-sramek-verlag.at/fileadmin/user_upload/Koziol_BasicQuestions_ePDF_HighResOpen_FINAL.pdf $>$.

WEST, E. The Utility of the NESS Test of Factual Causation in Scots Law. (online) Accesible via: https://www.abdn. ac.uk/law/documents/The_Utility_of_the_NESS_Test_of_Factual_Causation_in_Scots_Law.pdf

\section{Contact information:}

JUDr. Norbert Adamov, PhD.

norbert.adamov@flaw.uniba.sk

Comenius University in Bratislava, Faculty of Law

Šafárikovo nám. č. 6

P. O. BOX 313

81000 Bratislava

Slovak Republic 